\title{
DNMT1 wt Allele
}

National Cancer Institute

\section{Source}

National Cancer Institute. DNMT1 wt Allele. NCI Thesaurus. Code C73655.

Human DNMT 1 wt allele is located in the vicinity of $19 p 13.2$ and is approximately $62 \mathrm{~kb}$ in length. This allele, which encodes DNA (Cytosine-5)-Methyltransferase 1, is involved in epigenetic modification of chromatin DNA and control of gene expression. 